\title{
Gastrointestinal parasitic infections of ruminants in extensive management system in Southwest, Nigeria
}

\author{
Bada, A. A. ${ }^{1 *}$, Adewole, S. $0 .^{2}$, Olofintoye, L. K. ${ }^{2}$ and Omotoriogun T. C. ${ }^{1}$ \\ ${ }^{1}$ Department of Biological Sciences, Elizade University, Ilara-Mokin, Ondo State, Nigeria. \\ 2Department of Zoology, Ekiti State University, Ado-Ekiti, Ekiti State, Nigeria. \\ ${ }^{*}$ Corresponding author Email: glorynew.20@gmail.com
}

Copyright @ 2021 Bada et al. This article remains permanently open access under the terms of the Creative Commons Attribution License 4.0, which permits unrestricted use, distribution, and reproduction in any medium, provided the original work is properly cited.

Received 22nd April, 2021; Accepted 14th June, 2021

\begin{abstract}
Parasitic diseases are major impediments and causes of mortality and morbidity in animals leading to drastic decrease in economic returns in livestock production. This study was carried out to investigate the prevalence of gastrointestinal parasites among free-ranging ruminant species; with the objectives to determine difference in parasitic infection among ruminant species, and difference in parasitic infection between the sexes and age of the ruminant species. Random sampling method was used to collect small quantity of feaces from individual ruminants $(n=54)$. Direct smear method was used to identify the eggs of the helminths in ruminant species. Chi-square test was used to test the hypotheses of the study. Higher prevalence of gastrointestinal parasite was found in Capra hircus relative to Ovis aries and Bos taurus. Both nematodes (Trichostrongylu ssp, Haemonchus contortus, Strongloides papillous, Sygamus larygenes and Ascaris $s p$; and trematodes (Fasciola gigantica and Dicrocoelium dendriticum) were found in the ruminant in this study. Trichostrongylu ssp and Fasciola gigantica showed higher prevalence than other gastrointestinal parasites. Young and female had higher infection of helminths than adult and male of the studied ruminant species. Preventing economic loss due to helminthic parasitic infections rely on available data, which in turn is paramount to guide effective coordination of animal health care system.
\end{abstract}

Keywords: Direct smear, economy, helminth, nematode, trematode.

\section{INTRODUCTION}

Parasitic diseases are major impediments and causes of mortality and morbidity in animals; consequently, leading to drastic decrease in efficiency and economic returns in livestock production globally (Badran et al., 2012; Akanda et al., 2014; Hoste et al., 2006; Nwosu et al., 2007; Majeed et al., 2015; Hassan et al., 2019). Though, the economic loses of parasitic infection are difficult to measure; there are reports of these loses in some studies (Nieuwhof and Bishop, 2005; Schweizer et al., 2005; Selzer and Preface, 2009; Charlier et al., 2009; Morgan et al., 2013). The immediate loses associated with animals infected with gastrointestinal parasites includes reduced growth rate and fecundity; poor-quality hides, skin, milk and meat production; and also, weight loss (Morgan et al., 2013).

The systems (intensive and extensive) of livestock production may play key role in parasitic infections. In contrast to intensive system, extensive system (also freeranging) involves unrestricted movement of animals, feeding on a variety of indiscriminate food substrates (Nakayima et al., 2019). Free-ranging system is mostly adopted for livestock production in developing countries due to its low-cost and affordability. However, animals tend to feed indiscriminately in this system; therefore, easily prone to parasitic infections upon contact with infested substrates during the grazing period and/or foraging activities.

Helminth infection such as schistosomiasis, ascarisis, tricuriasis, drancunuliasis, and strongyloidiasis are well documented, and among neglected diseases affecting ruminants in tropical Africa (Zeryehun, 2012; Ovutor et al., 2014). All major group of helminths such as roundworm, flatworm, and tapeworm simultaneously occur in ruminants 
(Obiora et al., 2009). For example, goats and sheep were found infected with Oesoghagostomum, Bunostomum and Trichostrongyle including Haemonchus, Nematodirus, Strongyloides, and Cooperia, Trichostrongylus, Trichris and Strongylus (Anderson, 2000; van Dijk and Morgan, 2008; Rehbein et al., 2013;). Co-occurrence of parasites contributes to elevate the pathogenic effect in the animals.

The life-cycle of development and adaptations of helminth parasites make it easier to infect ruminants (Roeber et al., 2013). Susceptibility, severity and rate of infection of ruminants depend on the parasite species, and density of worms present in the gastrointestinal tract. Similarly, health and immunological status of the host, climatic conditions and available pasture including level of stress and management strategies can have stronger influence on gastrointestinal parasitic infection in ruminants (Zvinorova et al., 2016).

Moreover, certain risk factors such as age, sex, body condition, genetic diversity and behaviour have been associated with parasitic infection of host animals (Zvinorova et al., 2013). Animals of low-immune or immuno-compromised status, and those exposed to high infection pressure from helminth larval-contaminated environment are more likely to be heavily affected (Roeber et al., 2013; Kaplan, 2004). Despite available studies on ruminant parasites, there are scanty information on hostparasite specificity and differential infection between sexes and/or age groups in ruminant species in Nigeria. Thus, the objectives of this study were to investigate the prevalence of gastrointestinal parasitic infection in freeranging ruminant species; and to evaluate the ruminant parasite specificity; examine the effect of age on ruminants-parasite infection, and difference in parasite infection in the sexes in ruminant species in Southwest, Nigeria.

\section{MATERIALS AND METHODS}

\section{Study area}

Samples were collected from nine Local Government Areas namely; Oye, Ikole, Ido, Ikere, Ise-orun, Emure, Ado-Ekiti, ljero, and Efon-Alaaye; distributed in three Senatorial Districts (Ekiti North, Ekiti South and Ekiti Central Senatorial districts) in Ekiti State, Nigeria. All sites are located between latitudes $60^{\circ} 201^{\prime}$ to $80^{\circ} 101^{\prime} \mathrm{N}$ and longitudes $40^{\circ} 201^{\prime}$ to $50^{\circ} 401^{\prime} \mathrm{E}$.

\section{Sample collection}

Random sampling method was used to collect faecal samples from, goat, Capra aegagrus hircus, sheep, Ovis aries and cattle, Bos taurus. A total of 54 ruminant individuals i.e., 18 individuals from each of the ruminant species, were collected in the morning (between 08:00 to
10:00 hours GMT). Glove-protected hand was passed through the rectum of each ruminant for faeces collection, and preserved in wide-mouthed, sterilized and leak-proof containers before transported on the same day to the veterinary hospital laboratory in Ado-Ekiti, Nigeria. The sampled animals were aged and sexed accordingly during the sampling period.

\section{Microscopic examination of samples}

Direct detection and identification of parasitic infection was carried out using microscopic examination of faecal materials. The faeces were first examined for hardness, softness, watery, presence of blood, mucus, coloration and odour. Thereafter, about $0.5 \mathrm{~g}$ of faecal sample was collected from the container using a spatula and placed on a slide and emulsified with a drop of normal saline and iodine solutions following the procedure of Beatrice et al. (2013). The slides with cover-slip were examined under the microscope at $400 \times$ magnifications resolution for eggs and larvae of helminths.

\section{Data analysis}

Data analysis was carried out using $R$ package version 3.1.2 (R Development Core Team (2018). Chi-square was used to test variation in the prevalence of gastrointestinal parasitic infection of ruminant species, and parasitic infection difference between sexes (male and female), and ages (young and adult) were determined for the ruminant species.

\section{RESULTS}

Overall, $38.8 \%(n=21)$ of the 54 samples collected from ruminants were infected with gastrointestinal parasites. Both infected and non-infected faecal samples were lightgreen, brownish or dark coloured, exhibiting non-mucoidal and bloody characteristics. Five nematodes (Trichostrogyle spp, Haemonchus contortus, Strongyloides papillous, Ascaris sp, Syngamus laryngenes) and two trematodes (Fasciola gigantica, Dicrocoelium dendriticum) parasites were identified in the samples collected from the ruminant species (Figure 1).

Polyparasitism was observed across ruminants, for example Capra hircus and Ovis aries were co-infected by Trichostrongylus, Haemonchus and Strongyloides. Infection of Ascaris sp and Dicrocoelium were exclusive to Capra hircus; whereas Faciola and Syngamus was exclusively detected in Bos taurus. Generally, the prevalence in gastrointestinal parasites across ruminant species (Table 1) was higher for Trichostrongylus than other parasites.

The observed infection in each ruminant species as 


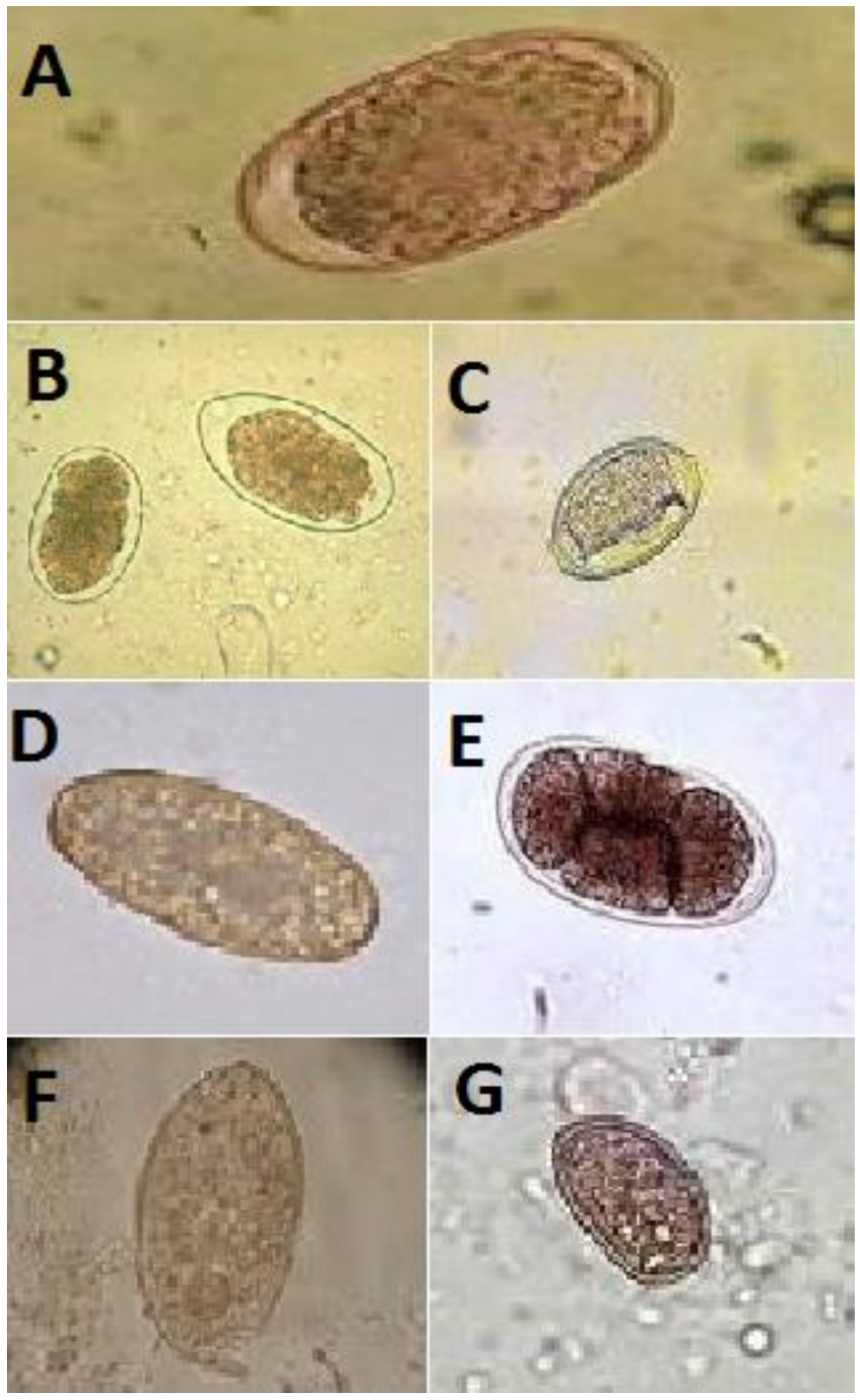

Figure 1. Eggs of helminth parasites detected in feces of ruminants, AHaemonchus contortus, B- Trichostrogyle spp., C- Strongyloides papillous., D- Ascaris sp., E- Syngamus laryngenes., F- Fasciola gigantica., and G- Dicrocoelium dendriticum, in samples collected from ruminants in Ekiti State, Nigeria.

Table 1. Gastrointestinal parasites infection (\%) based on sex and age of ruminant species examined in Ekiti State, Nigeria. $N$, total number of sexes and/or age examined across species; $n$, number of individual of the sexes and/or age examined for each species. Young ruminant $\geq 1$ to $\leq 5$ months old, and adult $\geq 6$ months old.

\begin{tabular}{lccccc}
\hline \multirow{2}{*}{ Species } & \multicolumn{2}{c}{ Sex } & & \multicolumn{2}{c}{ Age } \\
\cline { 2 - 3 } \cline { 5 - 6 } \cline { 5 - 6 } \cline { 5 - 6 } Capra hircus & $30 \%(n=5)$ & $16.7 \%(n=13)$ & & $16.7 \%(n=11)$ & \\
Ovis aries & $0 \%(n=3)$ & $15.9 \%(n=15)$ & & $16.7 \%(n=12)$ & \\
Bos taurus & $0 \%(n=2)$ & $11.4 \%(n=16)$ & & $8.3 \%(n=13)$ & $5.6 \%(n=6)$ \\
Summary & $30 \%(N=10)$ & $41.0 \%(N=44)$ & & $38.9 \%(N=36)$ & $11.1 \%(n=5)$ \\
\hline
\end{tabular}


Table 2. Gastrointestinal parasitic infection and prevalence in ruminants within Ekiti State, Nigeria.

\begin{tabular}{|c|c|c|c|c|c|c|c|c|}
\hline \multirow{2}{*}{ Species } & \multicolumn{7}{|c|}{ Gastrointestinal helminth parasites detection } & \multirow{2}{*}{ Infection } \\
\hline & Trichostrongylus & Haemonchus & Strongyloides & Ascaris & Fasciola & Syngamus & Dicrocoelium & \\
\hline Capra hircus & $7.41 \%(n=4)$ & $1.8 \%(n=1)$ & $3.7 \%(n=2)$ & $1.8 \%(n=1)$ & ND & ND & $1.8 \%(n=1)$ & $16.7 \%(n=9)$ \\
\hline Ovis aries & $7.41 \%(n=4)$ & $3.7 \%(n=2)$ & $1.8 \%(n=1)$ & ND & ND & ND & ND & $12.9 \%(n=7)$ \\
\hline Bos taurus & ND & ND & ND & ND & $7.41 \%(n=4)$ & $1.8 \%(n=1)$ & ND & $9.3 \%(n=5)$ \\
\hline Prevalence & $14.82 \%(n=8)$ & $5.6 \%(n=3)$ & $5.6 \%(n=3)$ & $1.8 \%(n=1)$ & $7.41 \%(n=4)$ & $1.8 \%(n=1)$ & $1.8 \%(n=1)$ & \\
\hline
\end{tabular}

ND- not detected.

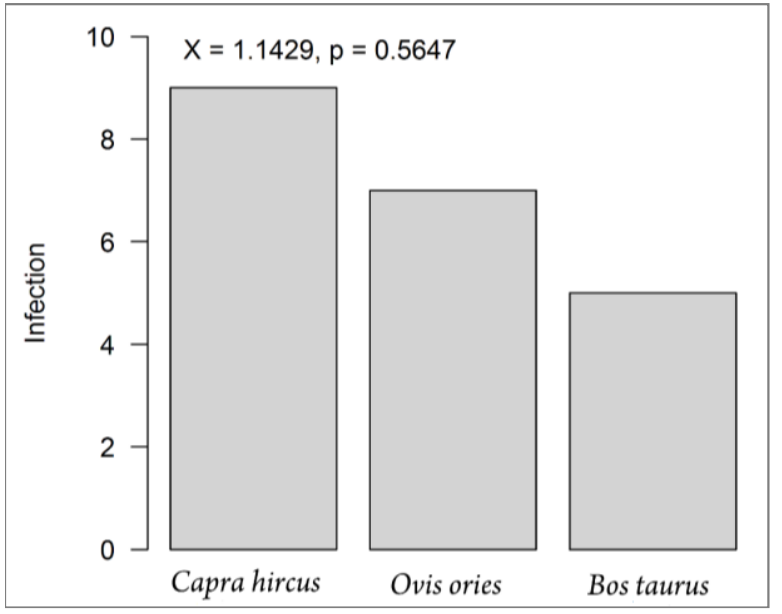

Figure 2. The gastrointestinal parasites infection comparing between infected case among species of ruminant in Ekiti State, Nigeria.

follows: Capra hircus $(16.7 \%, \mathrm{n}=9)$, Ovis aries $(12.9 \%, n=7)$ and Bos Taurus $(9.3 \%, n=5)$ (Table 1). There was no significance difference in gastrointestinal parasitic infection among ruminant species $\left(X^{2}=1.143, d f=2, p=0.564\right.$; Figure 2$)$.

Of the sexes, the difference in infection between male and female of the ruminant species was significant $\left(X^{2}=10.714, d f=1, p=0.001\right.$; Figure 3$)$. Thirty percent $(30 \%)$ of sampled males $(n=10)$

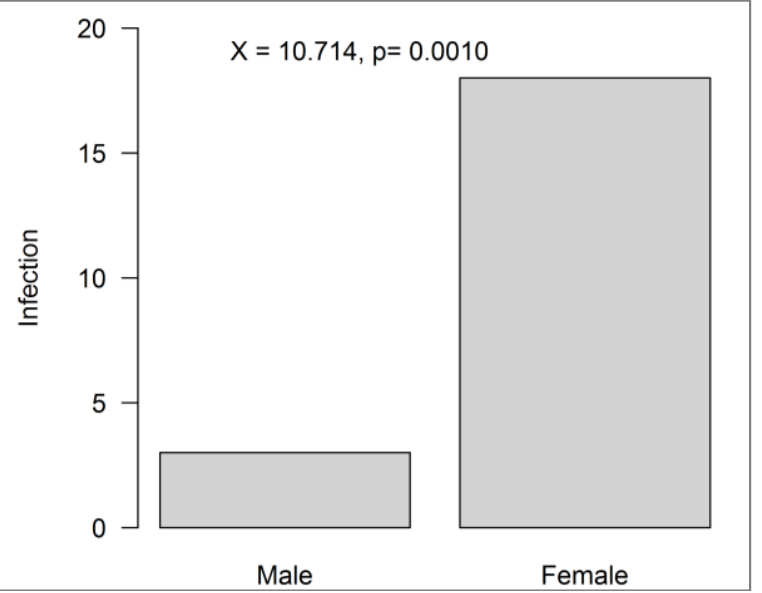

Figure 3. The gastrointestinal parasites infection capering between infected male and female of ruminant in Ekiti State, Nigeria.

were infected, this infection was exclusive to male of Capra hircus; and $41.0 \%$ of females $(n=44)$ were infected across the ruminant species (Table 2). Gastrointestinal parasitic infection was higher in females than males.

Similarly, there was a significant difference in parasitic infection between young and adult $\left(\mathrm{X}^{2}=\right.$ $3.8571, \mathrm{df}=1, \mathrm{p}=0.049$; Figure 4 ). $39 \%$ of young $(n=36)$ and $33 \%$ of adult $(n=18)$ ruminants were

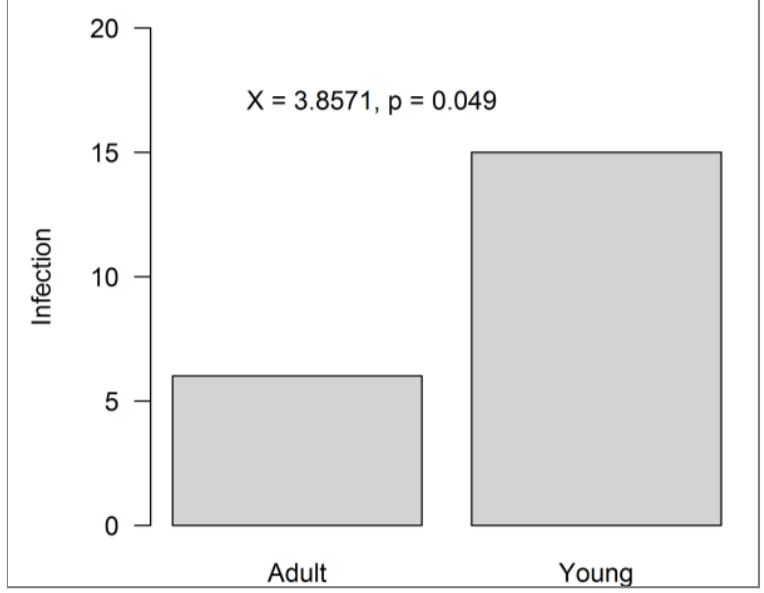

Figure 4. The gastrointestinal parasites infection comparing between infected young and adult of ruminant in Ekiti State, Nigeria.

infected (Table2). Number of young infected appears slightly higher than adult.

\section{DISCUSSION}

In this study, gastrointestinal parasitic infection was examined in three ruminant species. Infected and noninfected faecal samples had the common 
nature of faeces from ruminants, and were not different in appearance, character and coloration. Polyparasitism and co-infection of parasites was observed in the ruminants. Mixed infection can be the important cause of morbidity, loss of reproduction and increase susceptibility of ruminants to other diseases (Wang et al., 2006; Abebe and Esayas, 2011). Moreover, exclusive infection of Ascaris was found in Capra hircus; and Faciola and Syngamus in Bos taurus. Higher infection of parasites was observed in Capra hircus relative to the Ovis aries and Bos taurus (Table 1). Higher gastrointestinal parasitic infection observed in Capra hircus than Ovis aries and Bos taurus in the present study agrees with studies that showed higher prevalence of gastrointestinal parasite in ruminant species (Pawel et al., 2004; Risso et al., 2015; Singh et al., 2015; Jena et al., 2018). This may be attributed to the exposure of Capra hircus to contaminated pasture by different types of parasites. Parasites from both nematode and trematode were identified in the samples. Nematodes occurrence was highest in Capra hircus (Table 1), which agrees with the report of Kumsa et al. (2010) and Amadi et al. (2012). Specifically, Trichostrongylus eggs were highly prevalent in both Ovis aries and Bos taurus as reported in Abebe and Esayas, (2011) and Kumsa et al. (2010).

The feeding habit of free-ranging ruminants can encourage higher infection of gastrointestinal helminth parasites. Larvae of most parasites such as Haemonchus contortus, Syngamus larygene, Fasciola gigantica, Dicrocoelium dendriticum cling to the blades of grasses which can be easily ingested by the ruminants during grazing activities. In addition, nematodes exhibit a broadrange of host infection than trematodes. The humid tropical environment has been considered favourable for the development of various species of nematodes (Yadav, 2000; Hassan et al., 2019) and may have accounted for the highest occurrence in the ruminants in this study. Also, environmental factors favour survival of nematodes than trematodes, and transition between wet and dry seasons enhances the survival of some parasites than others; for example, Trichostrongylus $s p$. thrive rapidly in wet season than Haemonchus sp. The occurrence of Trichostrongylus $s p$. in the gut of ruminants causes profuse and persistent diarrhoea, this was observed in ruminants during field sampling in this study.

In this study, higher parasitic infection was observed in females than the males which agrees with a study in Ethiopia where higher prevalence of helminth infection was found in females (Dagnachew et al., 2011). Other studies have also documented that female are more susceptible to parasitic infections than male ruminants (Alexander and Stinson, 1988; Tariq et al., 2008; Jittapalapong et al., 2012; Zvinorova et al., 2016; Verma et al., 2018; Hassan et al., 2019). Male versus female differences in parasitic infection exist; the difference has been attributed to ecological, behavioural, or physiological differences between the sexes (Zuk and McKean 1996; Grear et al., 2009; Poulin, 1996; Fuxjager et al., 2011;
Kiffner et al., 2013). The reason for the higher prevalence of gastrointestinal parasites in female than male in this present study is not clear. There is suggestion that female reproductive behaviour and activities such as gestation, parturition, breast feeding and care of young- can suppress their immunity; therefore, making them easily susceptible to infection (Krishnan et al., 1996; Lloyd, 1983). Also, females eat more voraciously after delivery of their young, and may pick up eggs of these parasites in their food. In contrast, there are studies that showed malebiased parasitic infections, which has been attributed to immunosuppressive effect of testosterone leading to increase susceptibility of infection in the males (Folstad and Karter, 1992; Klein, 2004).

Also, this study observed higher parasitic infection in the young than adult ruminants. This corroborates previous study in Ethiopia (Dagnachewa et al., 2011), in which age influenced the prevalence of helminthiasis, and the higher susceptibility of younger animals (Keyyu et al., 2003). There is potential for direct and indirect association between host age and parasitic infection as demonstrated in other studies that showed these interactions (Emiru et al., 2013; El-Shahawy, 2016; Verma et al., 2018). It has been suggested that adult individuals are less heavily infected as a consequence of changes in feeding or behavioural patterns, habitat utilization, or immunity acquisition (Kołodziej-Sobocińska, 2019) but also that adult animals have usually developed a stronger immunity and harbor lower infection levels (Kethineni et al., 2006). Young and subadult animals with immature immune systems are most susceptible to infection (Cornell et al., 2008; Kethineni et al., 2006; Treboganova, 2010; Woolhouse, 1998; Bush et al., 2001; Kaplan, 2004; Roeber et al., 2013). Also, young ruminants can be infected through breast-feeding (milk) and/or placental during pregnancy (Coati et al., 2004; Lee et al., 1976).

\section{Conclusion}

This study showed that young and female ruminant animals were more infected than male and adult. Young and female are crucial to animal production and management of these animals can be achieved through strategic deworming using broad-spectrum anthelmintic plants that are effective against gastrointestinal infections. Veterinarians should constantly advice pastorals and ruminants' owners on control and preventive measure of gastrointestinal helminths in Ekiti State in other to improve returns from livestock production.

\section{CONFLICTING INTERESTS}

The authors declare that they have not conflict of interest.

\section{REFERENCE}

Abebe, W., \& Esayas, G. (2001). Survey of ovine and caprine 
gastro-intestinal helminthosis in eastern part of Ethiopia during the dry season of the year. Revue de Medecine Veterinaire, 152(5), 379-384.

Akanda, M. R., Hasan, M. M. I., Belal, S. A., Roy, A. C., Ahmad, S. U., Das, R., \& Masud, A. A. (2014). A survey on prevalence of gastrointestinal parasitic infection in cattle of Sylhet division in Bangladesh. American Journal of Phytomedicine and Clinical Therapeutics, 2(7), 850-860.

Alexander, J., \& Stimson, W. H. (1988). Sex hormones and the course of parasitic infection. Parasitology Today, 4(7), 189193.

Badran, I., Alumor, J., Aref, R., Abuamsha, R., \& Alqisi, W. (2012). Prevalence and diversity of gastrointestinal parasites in small ruminants under two different rearing systems in Jenin district of Palestine. An-Najah University Journal for Research, $26,1-18$.

Bush, A. O., Fernandez, J. C., Esch, G. W., \& Seed, J. R. (2001). Immunological, pathological, and biochemical aspects of parasitism. In: Bush, A. O., Fernandez, J. C., Esch, G. W., \& Seed, J. R. (eds.). Parasitism: The diversity and ecology of animal parasites. Cambridge University Press, United Kingdom. Pp 13-42.

Charlier, J., Höglund, J., von Samson-Himmelstjerna, G., Dorny, P., \& Vercruysse, J. (2009). Gastrointestinal nematode infections in adult dairy cattle: impact on production, diagnosis and control. Veterinary Parasitology, 164(1), 70-79.

Coati, N., Schnieder, T., \& Epe, C. (2004). Vertical transmission of Toxocara cati Schrank 1788 (Anisakidae) in the cat. Parasitology Research, 92(2), 142-146.

Cornell, S. J., Bjornstad, O. N., Cattadori, I. M., Boag, B., \& Hudson, P. J. (2008). Seasonality, cohort-dependence and the development of immunity in a natural host-nematode system. Proceedings of the Royal Society B: Biological Sciences, 275(1634), 511-518.

Dagnachew, S., Amamute, A., \& Temesgen, W. (2011). Epidemiology of gastrointestinal helminthiasis of small ruminants in selected sites of North Gondar zone, Northwest Ethiopia. Ethiopian Veterinary Journal, 15(2), 73-79.

El-Shahawy, I. S. (2016). Coproscopic study on enteric protozoan parasites of goats (Capra hircus L., 1758) in Upper Egypt. Pakistan Journal of Zoology, 48(5), 1477-1483.

Emiru, B., Amede, Y., Tigre, W., Feyera, T., \& Deressa, B. (2013). Epidemiology of gastrointestinal parasites of small ruminants in Gechi District, Southwest Ethiopia. Advances in Biological Research, 7(5), 169-174.

Folstad, I., \& Karter, A. J., (1992). Parasites, bright males, and the immunocompetence handicap. The American Naturalist, 139(3), 603-622.

Fuxjager, M. J., Foufopoulos, J., Diaz-Uriarte, R., \& Marler, C. A. (2011). Functionally opposing effects of testosterone on two different types of parasite: implications for the immunocompetence handicap hypothesis. Functional Ecology, 25(1), 132-138.

Grear, D. A, Perkins, S. E., \& Hudson, P. J (2009). Does elevated testosterone result in increased exposure and transmission of parasites? Ecology Letters, 12(6), 528-537.

Hassan, N. M., Farag, T. K., El Ezz, N. M. A., \& Abou-Zeina, H. A. (2019). Prevalence assessment of gastrointestinal parasitic infections among goats in Giza Governorate, Egypt. Bulletin of the National Research Centre, 43, Article number 127.

Hoste, H., Jackson, F., Athanasiadou, S., Thamsborg, S. M., \& Hoskin, S. O. (2006). The effects of tannin-rich plants on parasitic nematodes in ruminants. Trends in Parasitology, 22(6), 253-261.
Jena, A., Deb, A. R., Kumari, L., Biswal, S. S., \& Joshi, S. K. (2018). Prevalence of gastrointestinal helminthes among goats in and around Ranchi, Jharkhand, India. International Journal of Current Microbiology and Applied Sciences, 7(1), 35063513.

Jittapalapong, S., Saengow, S., Pinyopanuwat, N., Chimnoi, W., Khachaeram, W., \& Stich, R. W. (2012). Gastrointestinal helminthic and protozoal infections of goats in Satun, Thailand. The Journal of Tropical Medicine and Parasitology, 35(2), 48-54.

Kaplan, R. M. (2004). Drug resistance in nematodes of veterinary importance: a status report. Trends in Parasitology, 20(10), 477-481.

Kethineni, N., Brummer, E., \& Stevens, D. A. (2006). Susceptibility to pulmonary blastomycosis in young compared to adult mice: immune deficiencies in young mice. Medical Mycology, 44(1), 51-60.

Keyyu, J. D., Kassuku, A. A., Kyvsgaard, N. C., \& Willingham, A. L. (2003). Gastrointestinal nematodes in indigenous Zebu cattle under pastoral and nomadic management systems in the lower plain of the Southern Highlands of Tanzania. Veterinary Research Communications, 27(5), 371-380.

Kiffner, C., Stanko, M., Morand, S., Khokhlova, I. S., Shenbrot, G. I., Laudisoit, A., Leirs, H., Hawlena, H., \& Krasnov, B. R. (2013). Sex-biased parasitism is not universal: evidence from rodent-flea associations from three biomes. Oecologia, 173(3), 1009-1022.

Klein, S. L. (2004). Hormonal and immunological mechanisms mediating sex differences in parasite infection. Parasite Immunology, 26(6-7), 247-264.

Kołodziej-Sobocińska, M. (2019). Factors affecting the spread of parasites in populations of wild European terrestrial mammals. Mammal Research, 64(3), 301-318.

Krishnan, L., Guilbert, L. J., Russell, A. S., Wegmann, T. G., Mosmann, T. R., \& Belosevic, M. (1996). Pregnancy impairs resistance of C57BL/6 mice to Leishmania major infection and causes decreased antigenspecific IFN-gamma responses and increased production of $\mathrm{T}$ helper 2 cytokines. Journal of Immunology, 156(2), 644-652.

Kumsa, B., Tolera, A., \& Nurfeta, A. (2011). Comparative efficacy of seven brands of albendazole against naturally acquired gastrointestinal nematodes in sheep in Hawassa, southern Ethiopia. Turkish Journal of Veterinary and Animal Sciences, 34(5), 417-425.

Lee, K-T., Min, H-K., \& Soh, C-T. (1976). Transplacental migration of Toxocara canis larvae in experimentally infected mice. Journal of Parasitology, 62(3), 460-465.

Lloyd, S. (1983). Effect of pregnancy and lactation upon infection. Veterinary Immunology and Immunopathology, 4(1-2), 153176.

Majeed, Q. A., Alazemi, M. S., Henedi, A. A., \& Tahrani, L. (2015). Study on parasites from farm animals in Kuwait. Journal of the Egyptian Society of Parasitology, 45(1), 71-74.

Morgan, E. R., Charlier, J., Hendrickx, G., Biggeri, A., Catalan, D., Samson-Himmelstjerna, V., Demeler, J., Müller, E., Van Dijk, J., Kenyon, F., \& Vercruysse, J. (2013). Global change and helminth infections in grazing ruminants in Europe: impacts, trends and sustainable solutions. Agriculture, 3(3), 484-502.

Nakayima, J., Arinaitwe, E., Kabasa, W. M., Kasaija, P. D., Agbemelo-Tsomafo, C., \& Omotoriogun, T. C. (2019). Phylogeny and prevalence of haemosporidian parasites of free-ranging domestic birds in Northwestern Uganda. 
International Journal of Livestock Research, 9(12), 244-258

Nieuwhof, G. J., \& Bishop, S. C. (2005). Costs of the major endemic diseases of sheep in Great Britain and the potential benefits of reduction in disease impact. Animal Science, 81(1), 23-29.

Nwosu, C. O., Madu, P. P., \& Richards, W. S. (2007). Prevalence and seasonal changes in the population of gastrointestinal nematodes of small ruminants in the semi-arid zone of northeastern Nigeria. Veterinary parasitology, 144(1-2), 118-124.

Owhoeli, O., Elele, K., \& Gboeloh, L. B. (2014). Prevalence of gastrointestinal helminths in exotic and indigenous goats slaughtered in selected abattoirs in Port Harcourt, south-south, Nigeria. Chinese Journal of Biology, Volume 2014, Article ID 435913, 8 pages.

Poulin, R. (1996). Helminth growth in vertebrate hosts: does host sex matter? International Journal for Parasitology, 26(11), 1311-1315.

R Development CORE TEAM (2010). A language and environment for statistical computing. $R$ Foundation for Statistical Computing, Vienna, Austria. URL http://www.Rproject.org.

Rehbein, S., Baggott, D. G., Johnson, E. G., Kunkle, B. N., Yazwinski, T. A., Yoon, S., Cramer, L. G., \& Soll, M. D. (2013). Nematode burdens of pastured cattle treated once at turnout with eprinomectin extended-release injection. Veterinary Parasitology, 192(4), 321-331.

Risso, A., Kessler, J. D., Soriano, V. S., Nunes, M. L. A., Machado, G., Langaro, A., Rossetto, R., Zuffo, T., Dallago, M., Castro, P., \& Silva, A. S. D. (2015). Influence of pathological conditions caused by gastrointestinal parasites infection on pregnant ewe's behavior. Acta Scientiae Veterinariae, 43, Article number 1283.

Roeber, F., Jex, A. R., \& Gasser, R. B. (2013). Impact of gastrointestinal parasitic nematodes of sheep, and the role of advanced molecular tools for exploring epidemiology and drug resistance-an Australian perspective. Parasites \& Vectors, 6 , Article number 153.

Schweizer, G., Braun, U., Deplazes, P., \& Torgerson, P. R. (2005). The economic effects of bovine fasciolosis in Switzerland. Veterinary Record, 157(7), 188-93.

Selzer, P. M. (2009). Antiparasitic and antibacterial drug discovery. from molecular targets to drug candidates; WileyBlackwell: Hoboken, USA. Pp. 11-12.
Singh, A. K., Das, G., Roy, B., Nath, S., Naresh, R., \& Kumar, S. (2015). Prevalence of gastrointestinal parasitic infections in goat of Madhya Pradesh, India. Journal of Parasitic Diseases, 39(4), 716-719.

Tariq, K., Chishti, M., Ahmad, F., \& Shawl, A. (2008) Epidemiology of gastrointestinal nematodes of sheep managed under traditional husbandry system in Kashmir valley. Veterinary Parasitology, 158(1),138-143.

Treboganova, N. (2010). Behavior of the bison and helminthoses. European Bison Conservation Newsletter, 3,125-134.

van Dijk, J., and Morgan, E. R. (2008). The influence of temperature on the development, hatching and survival of Nematodirus battus larvae. Parasitology, 135(2), 269.

Verma, R., Sharma, D. K., Paul, S., Gururaj, K., Dige, M., Saxena, V. K., Rout, P. K., Bhusan, S., \& Banerjee, P. S. (2018). Epidemiology of common gastrointestinal parasitic infections in goats reared in semi-arid region of India. Journal of Animal Research, 8(1), 39-45.

Wang, C. R., Qui, J. H., Zhu, X. Q, Han, X. H., Ni, H. B., Zhao, J. P., Zhou, Q. M., Zhang, H. W., \& Lun, Z. R. (2006). Survey of helminths in adult sheep in Helogjlang Province, People Republic of China. Veterinary Parasitology, 140, 376-380.

Woolhouse, M. E. J. (1998). Patterns in parasite epidemiology: the peak shift. Parasitology Today, 14(10), 428-434.

Yadav, C. L. (2000). Agro-climatic influence on parasitic disease of sheep and goats. Pashudhan, 15, 1

Zeryehun, T. (2012). Helminthosis of sheep and goats in and around Haramaya, Southeastern Ethiopia. Journal of Veterinary Medicine and Animal Health, 4(3), 48-55.

Zuk, M., \& McKean, K. A. (1996). Sex differences in parasite infections: patterns and processes. International Journal for Parasitology, 26(10), 1009-1023.

Zvinorova, P. I., Halimani, T. E., Muchadeyi, F. C., Matika, O., Riggio, V., \& Dzama, K. (2016). Prevalence and risk factors of gastrointestinal parasitic infections in goats in low-input lowoutput farming systems in Zimbabwe. Small Ruminant Research, 143, 75-83. 